\title{
(2) OPEN ACCESS \\ Successful transition from insulin to sulfonylurea, on second attempt, in a 24-year-old female with neonatal diabetes secondary to KCNJ11 gene mutation
}

\author{
Sulaiman Hajji, ${ }^{1}$ Khaled Aljenaee, ${ }^{2}$ Aoife Garrahy, ${ }^{1}$ Maria Byrne ${ }^{1}$
}

\begin{abstract}
${ }^{1}$ Endocrinology, Mater Misericordiae University Hospital, Dublin, Ireland ${ }^{2}$ Endocrine and Diabetes, Saint James's Hospital, Dublin, Ireland
\end{abstract}

Correspondence to Sulaiman Hajji; dr.sulaiman.hajji@gmail.com

Accepted 19 March 2021
Check for updates

(C) BMJ Publishing Group Limited 2021. Re-use permitted under CC BY-NC. No commercial re-use. See rights and permissions. Published by BMJ.

To cite: Hajji S, Aljenaee K, Garrahy A, et al. BMJ Case Rep 2021;14:e239973. doi:10.1136/bcr-2020239973

\section{SUMMARY}

Neonatal diabetes (NDM) is defined as diabetes that occurs in the first 6 months of life, the majority of cases are due to sporadic mutations. ATP-sensitive potassium channels located in the beta cells of the pancreas play a major role in insulin secretion and blood glucose homeostasis. Mutations that alter the function of these channels may lead to NDM. We report a case of a 26-year-old lrish woman who was diagnosed with NDM at the age of 4 weeks and treated as type 1 diabetes mellitus, with multiple daily injections of insulin with suboptimal glycaemic control and frequent episodes of hypoglycaemic. She underwent genetic testing for NDM and was diagnosed with a KCNJ11 gene mutation. She was transitioned to high dose glibenclamide at the age of 16 years, but the trial failed due to poor glycaemic control and patient preference, and she was restarted on insulin. At 24 years of age, she was successfully transitioned from insulin (total daily dose 50 units) to high dose sulfonylurea (SU) (glibenclamide $15 \mathrm{mg}$ twice daily). This resulted in optimal control of blood glucose ( $\mathrm{HbA1C}$ fell from 63 to $44 \mathrm{mmol} / \mathrm{mol})$, lower rates of hypoglycaemic and better quality of life. This case demonstrates that a second trial of SU in later life may be successful.

\section{BACKGROUND}

Neonatal diabetes (NDM) occurs in approximately one in 100000-300000 live births and is mostly monogenic in nature. Mutations in KCNJ11 and ABCC8, encoding the two subunits kir6.2 and sulfonylurea receptors (SUR) of the ATP-sensitive potassium channel located on the beta cells of the pancreas respectively, can cause NDM. Identifying this type of monogenic diabetes carries many important implications for patient care; including the long-term management plan (sulfonylureas (SUs) rather than insulin therapy), expected disease course and complications. Appropriate therapy will result in better outcome, and quality of life. ${ }^{12}$

\section{CASE PRESENTATION}

We report a case of a 28-year-old Irish woman diagnosed initially with diabetes mellitus at the age of 4 weeks (1991). She was born at term and was small for gestational age, $2.6 \mathrm{~kg}$. She was admitted to hospital at 4 weeks of age with weight loss to $2.3 \mathrm{~kg}$, dehydration, fever, napkin and oral thrush. Her $\mathrm{HbA} 1 \mathrm{C}$ was $83.0 \mathrm{mmol} / \mathrm{mol}$, she was ketotic and her $\mathrm{pH}$ was 7.0. She was diagnosed and treated as type 1 diabetes mellitus. After adequate control of her blood glucose, she was discharged home on subcutaneous multiple daily injections (MDI) of insulin. Her anti-GAD and anti-islet cell antibodies were both negative. During her follow-up with the paediatric team, no developmental delay, seizure disorder or muscle weakness was identified. She has three healthy older brothers with no history of diabetes mellitus, but two members of her extended family had diabetes as shown in figure 1 family pedigree.

\section{INVESTIGATIONS}

The patient was admitted to hospital at 4 weeks of age and was diagnosed as type 1 diabetes mellitus and her anti-GAD and anti-islet cell antibodies were both negative.

At the age of 16 years (2007), she underwent genetic testing for NDM

and was diagnosed with a KCNJ11 gene mutation (R201H genotype).

\section{DIFFERENTIAL DIAGNOSIS}

She was diagnosed and treated as type 1 diabetes mellitus with MDI of insulin. Due to her onset of diabetes, a suspicion of NDM was raised and proven by genetic testing.

\section{TREATMENT}

At age of 16 , She was admitted to the hospital to facilitate transfer from insulin therapy to SU (glibenclamide) as per guidelines. ${ }^{2}$ She was taking Insulatard 24 units daily, Novorapid 2-3 units for breakfast and 9-10 units before dinner. She initially experienced nausea when she started glibenclamide and was treated with motilium. She persisted with SU therapy and was discharged home on a dose of $0.5 \mathrm{mg} / \mathrm{kg} /$ day. This was further increased as outpatient to $1 \mathrm{mg} / \mathrm{kg} / \mathrm{day}$, she weighed $68 \mathrm{~kg}$. Insulin therapy was never fully discontinued as she continued to take small doses of Novorapid premeals. And due to persistent elevation of her basal glucose levels, she was started on insulin detemir four units BD. She was tolerating the glibenclamide well, but in view of the fact that she had to inject insulin, she decided that she would prefer to just inject insulin and stopped the glibenclamide.

Four years later, she was referred to our adult service in 2011. Her diabetes was poorly controlled 


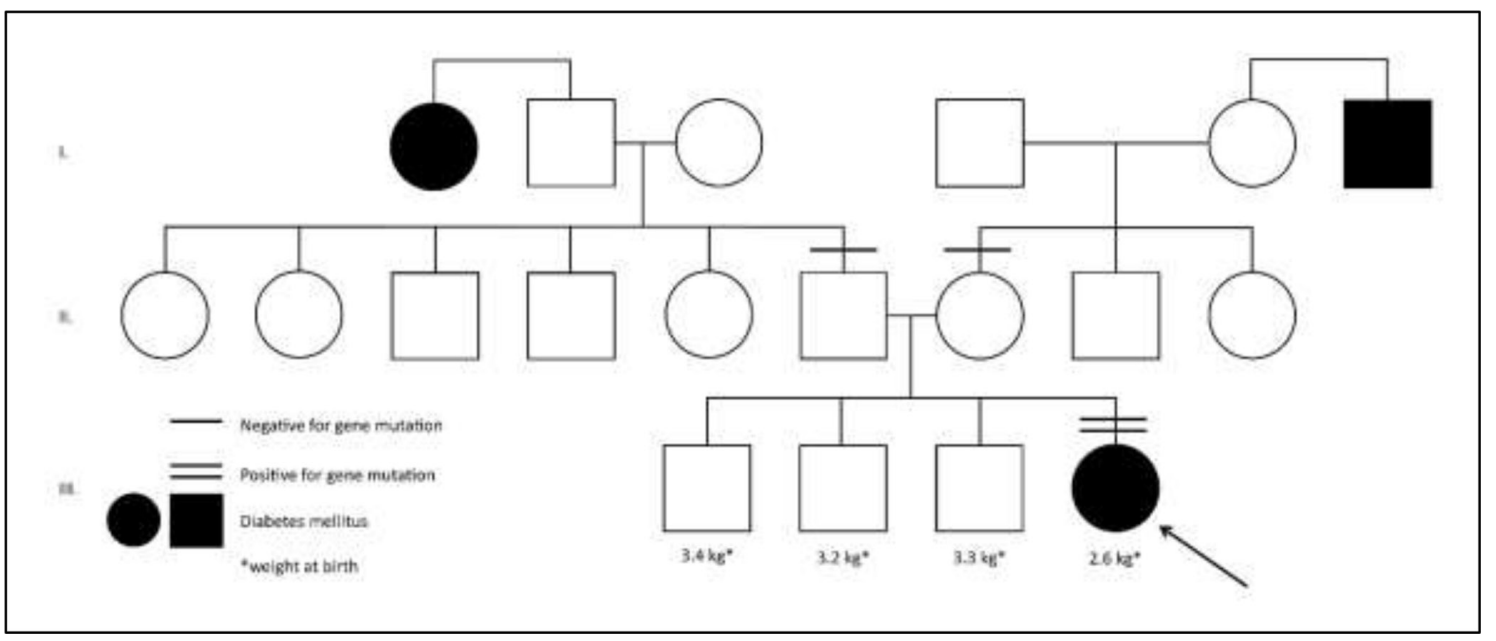

Figure 1 Family pedigree.

with an average $\mathrm{HbA1C}$ of $65-75 \mathrm{mmol} / \mathrm{mol}$ throughout the preceding years. She had a history of two hospital admissions due to symptomatic hypoglycaemic. Her only diabetic complication was background diabetic retinopathy, first diagnosed at age 19 years.

However, at the age of 24 years (2015), after attending a NDM meeting in Exeter, she wanted to retry SUs. Her HbA1C was $63 \mathrm{mmol} / \mathrm{mol}$ and her total daily dose of insulin was 50 units at that time. She was successfully transitioned to glibenclamide $0.44 \mathrm{mg} / \mathrm{kg} /$ day resulting in optimal diabetes control with a fall in $\mathrm{HbA} 1 \mathrm{C}$ to $44 \mathrm{mmol} / \mathrm{mol}$ over 2 years (figure 2). Her C-peptide level was $28 \mathrm{pmol} / \mathrm{L}$ postprandially-pre glibenclamide and $1680 \mathrm{pmol} / \mathrm{L}$ postprandially after starting glibenclamide.

\section{OUTCOME AND FOLLOW-UP}

She was maintained on glibenclamide $15 \mathrm{mg}$ po bd, the control of her blood sugar readings remained excellent with infrequent episodes of hypoglycaemic as shown in figure 3 demonstrating her daily patterns of glucose readings using libre freestyle over 2 weeks in 2017 on glibenclamide $15 \mathrm{mg}$ po bd, with HBAIC of $44 \mathrm{mmol} / \mathrm{mol}$ in 2017. The hypoglycemic episodes shown on the sensor data were not associated with symptoms and only detected by the sensor. Glibenclamide was increased to $0.57 \mathrm{mg} /$ $\mathrm{kg} /$ day $(20 \mathrm{mg}$ po bd) in September 2019 as her HbA1C rose to $57 \mathrm{mmol} / \mathrm{mol}$ when she was stressed at work with an inconsistent routine and eating more carbohydrate. Her HbA1C rose to $61 \mathrm{mmol} / \mathrm{mol}$ in January 2020. She has subsequently reduced glibenclamide to $15 \mathrm{mg}$ po bd in February 2020 because she was experiencing symptomatic hypoglycaemic at night $8-10$ hours after exercise on the higher dose. Her HbA1C dropped to $51 \mathrm{mmol} / \mathrm{mol}$ in March 2020. Apart from background diabetic retinopathy, she has no microvascular complications of diabetes. Her weight reduced from $69.7 \mathrm{~kg}$ in 2015 to $64 \mathrm{~kg}$ in 2020 . After 24 years on insulin therapy, the patient's quality of life is much improved with SU. She was following up every 3-6 months at diabetes centre-The Mater Misericordiae University Hospital, with marked improvement and control in her blood sugar readings and HbA1c levels.

\section{DISCUSSION}

The beta cells of the pancreas have a large number of glucose transporters (GLUT 2) that allow glucose influx into the beta cells at a rate that is proportional to blood glucose concentration. The glucose goes through physiological processes which ends in the formation of ATP. An increase in ATP leads to closure of ATP-sensitive potassium channels of the cell, with resultant

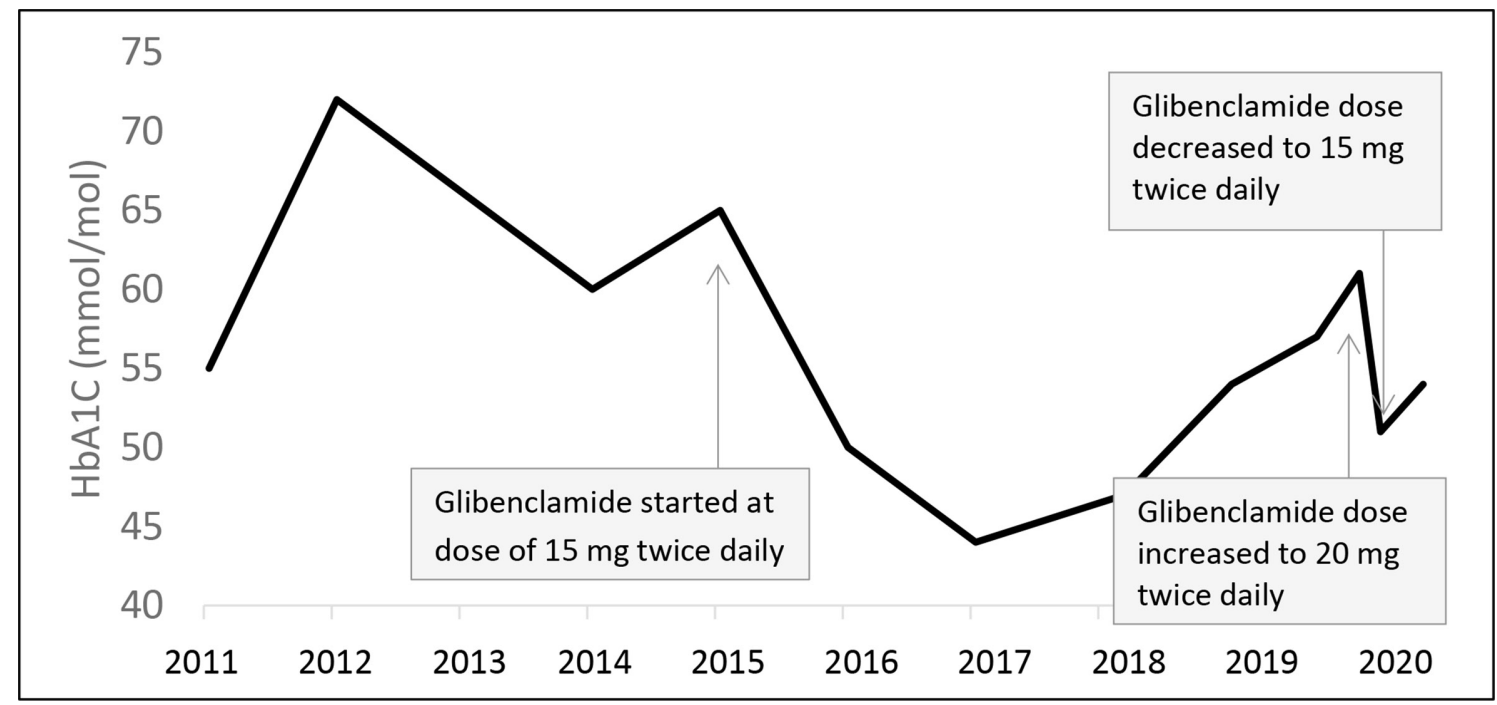

Figure $2 \mathrm{HbA} 1 \mathrm{C}$ trend over years (2011-2020) demonstrating marked improvement with glibenclamide. 


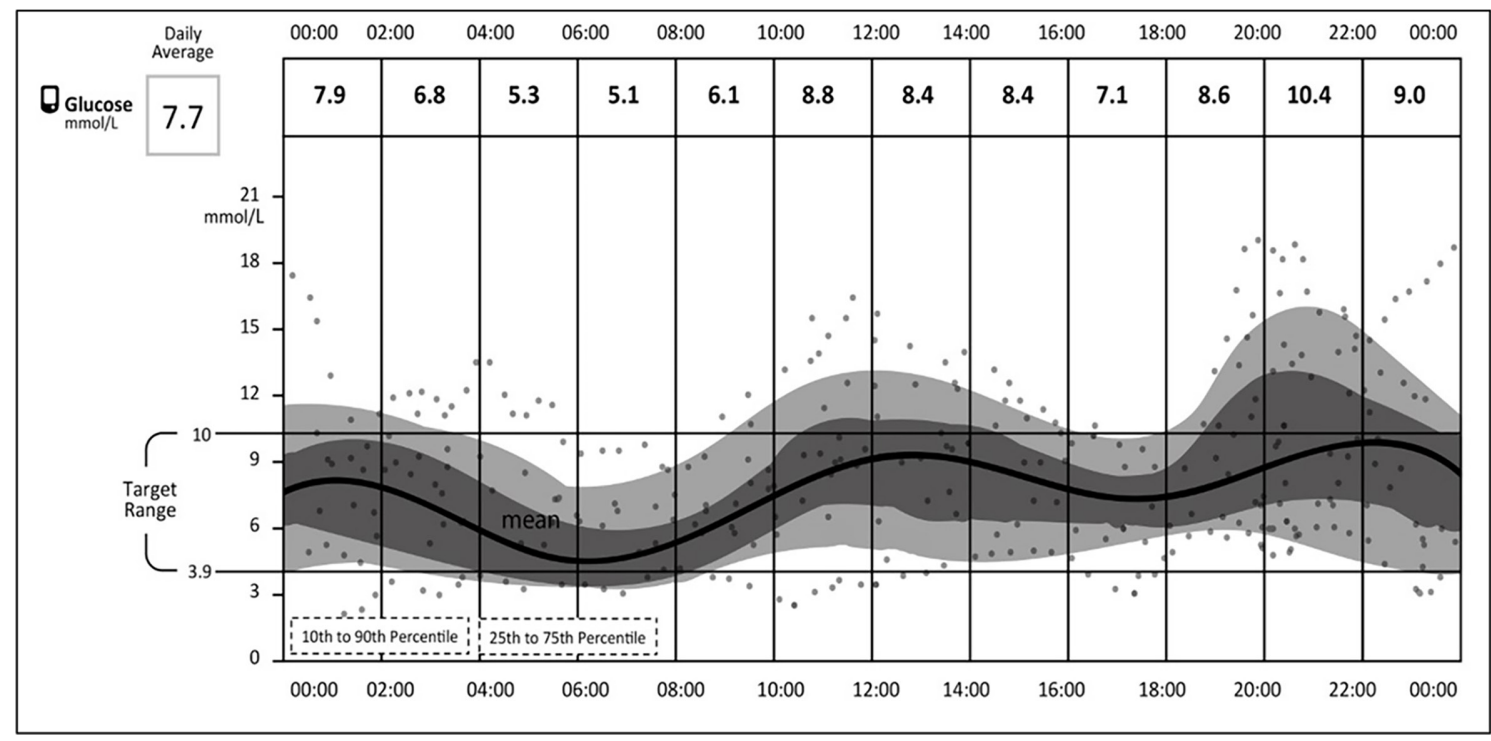

Figure 3 Daily patterns of glucose readings using libre freestyle over 2 weeks in 2017 on glibenclamide $15 \mathrm{mg}$ po bd.

depolarisation of the cell membrane thereby producing an influx of calcium that stimulate insulin secretion. ${ }^{3}$ ATP-sensitive potassium channels are composed of eight protein subunits including the family of Kir6.x (eg, Kir6.2) and the SUR. Heterozygous activating mutations in KCNJ11, which is the gene responsible for (Kir6.2) transcription, impairs the ability of ATP to close the channel; thereby inhibiting insulin secretion and leading to NDM.

Diabetes mellitus is an etiologically heterogeneous disorder, often classified into polygenic or monogenic disorders. Only $1 \%-2 \%$ of cases are secondary to a single gene mutation (monogenic). NDM is defined as diabetes that occurs within the first 6 months of life. Most cases of NDM are sporadic resulting from de novo mutations. The most common genetic cause of permanent NDM is an activating mutation in KCNJ11. ${ }^{4}$ Unless genetic testing is considered, this type of diabetes can be misdiagnosed as type 1 diabetes. The distinction between NDM and type 1 diabetes is crucial, as it informs treatment decisions (insulin vs SUs), understanding of associated conditions and surveillance of complications. ${ }^{12}$ NDM due to a mutation in KCNJ11 can be subdivided into two subgroups, those who had only diabetes and those who had diabetes and shared neurologic abnormalities. Low birth weight is a characteristic of most patients, as noticed in our patient. Developmental delay, muscle weakness, epilepsy and dysmorphic features (prominent metopic suture, a downturned mouth and bilateral ptosis) can also be features. ${ }^{5}$

The majority of cases of KCNJ11 mutations (approximately $90 \%$ ) can be transferred from insulin to oral SUs, leading to better glycaemic control, as is demonstrated in our case. The response to SUs is explained by the ability of the drug to close the mutant ATP-sensitive potassium channels, thereby increasing insulin secretion in response to glucose metabolism. ${ }^{2}$ While the majority of reported successfully transferred patients are children, the excellent response to SUs at the age of 24 years in our case supports the principle that the beta cells can survive and respond to SUs treatment even after decades of exogenous insulin treatment. ${ }^{46}$ In a retrospective cohort study of 58 individuals with NDM due to KCNJ11 mutations identified through the University of Chicago, ${ }^{6}$ the authors conclude that patients require higher doses of SUs if it was initiated at an older age, with 10/17 patients who initiated SU therapy after the age of 13 years requiring additional therapy to achieve glycaemic control. This can be explained by the age-related loss of beta cells. It was suggested that the beta cell population is established at a very young age, with decreasing proliferation occurring with increasing age during childhood. ${ }^{7}$ Despite this, previous studies, ${ }^{8}$ and our case, demonstrate that age should not be a contraindication to transition. The mutation subtype can also influence the success of transition to SUs and required dose (low vs high dose); variable response to SUs was observed from different genetic subtypes of KCNJ11 mutation including the R201H genotype of our case. ${ }^{9}$

In our case, the failure of the initial attempt to transition to SU therapy at age 16 highlights the complexities of diabetes management in this age group, while the successful transition at age 24 using an identical protocol emphasises the importance of reassessing treatment regimes in young adulthood. Puberty is very challenging in a child with diabetes. In puberty, several factors may contribute to poor glycaemic control; first, lean body mass doubles in a small period of time, so insulin requirement is increased. Second, insulin resistance is increased during the pre- and pubertal period. Third, certain behavioural changes occurring during adolescence may worsen glycaemic control. ${ }^{10}$ This may explain why transition to glibenclamide in our patient failed at age of 16 . In patients with NDM, the dose of glibenclamide should be increased as the teenager grows. So, during puberty, high dose of glibenclamide $(0.5-1 \mathrm{mg} / \mathrm{kg} /$ day $)$ is usually used. Increasing the dose in NDM is safe and is unlikely to cause any increase in hypoglycaemic risk, unlike in type 2 diabetes mellitus. ${ }^{11}$ However, postprandial hypoglycaemic is reported by patients with KCNJ11 on SU treatment due an inability to modulate insulin secretion in response to low carbohydrate meals. For that reason, it is recommended that affected patients avoid missed meals or meals lacking carbohydrate while on SU treatment. $^{12}$

Evidence is lacking regarding the most appropriate treatment of affected women with NDM during pregnancy. Usually, the choice to transfer to insulin is considered preconception but, if done too close to pregnancy, unstable glycaemic control can have potential consequences regarding fetal outcome. If the foetus inherits a $\mathrm{K}_{\mathrm{ATP}} \mathrm{NDM}$ mutation from their mother they have greatly reduced insulin secretion in utero that reduces fetal 
growth by $\sim 900 \mathrm{~g}$. Treating the mother with glibenclamide in the third trimester treats the affected foetus in utero, normalising fetal growth, but is not desirable, especially in the high doses used in this condition, if the foetus is unaffected. Our patient has been advised to attend our pre pregnancy clinic when she is planning pregnancy.

In summary, NDM secondary to KCNJ11 mutation should be considered in patients with diabetes mellitus diagnosed within the first 6 months of life. Often patients exhibit better glycaemic responses to SUs compared with MDI of insulin thereby improving quality of life and lowering the incidence of diabetes complications. In our case, the successful transition to SU at age 24 years highlights the importance of attempting transfer to SU in adult diabetic clinics, even if this failed during puberty.

\section{Learning points}

- Neonatal diabetes mellitus (NDM) secondary to KCNJ11 mutation should be considered in patients with diabetes mellitus diagnosed within the first 6 months of life.

- Patients with NDM exhibit better glycaemic responses to sulfonylureas (SU) compared with multiple daily injections of insulin.

- The importance of attempting transfer patient with NDM to SU in adult diabetic clinics, even if this failed during puberty.

\section{Twitter Sulaiman Hajji @dr_sulaiman_h}

Contributors $\mathrm{SH}$ was directly involved in patient care, conception and design by SH and KA; data interpretation by SH, KA and AG; report was written by SH, KA, AG and MB. All authors have contributed to the manuscript editing.

Funding The authors have not declared a specific grant for this research from any funding agency in the public, commercial or not-for-profit sectors.

Competing interests None declared.

Patient consent for publication Obtained.
Provenance and peer review Not commissioned; externally peer reviewed.

Open access This is an open access article distributed in accordance with the Creative Commons Attribution Non Commercial (CC BY-NC 4.0) license, which permits others to distribute, remix, adapt, build upon this work non-commercially, and license their derivative works on different terms, provided the original work is properly cited and the use is non-commercial. See: http://creativecommons.org/ licenses/by-nc/4.0/.

\section{REFERENCES}

1 Naylor RN, Greeley SAW, Bell GI, et al. Genetics and pathophysiology of neonatal diabetes mellitus. J Diabetes Investig 2011;2:158-69.

2 Pearson ER, Flechtner I, Njølstad PR, et al. Switching from insulin to oral sulfonylureas in patients with diabetes due to Kir6.2 mutations. N Engl J Med 2006;355:467-77.

3 Akrouh A, Halcomb SE, Nichols CG, et al. Molecular biology of K(ATP) channels and implications for health and disease. IUBMB Life 2009;61:971-8.

4 Greeley SAW, Zielinski MC, Poudel A. Case Report: Preservation of Reduced Numbers of Insulin-Positive Cells in Sulfonylurea-Unresponsive KCNJ11 -related Diabetes. J Clin Endocrinol Metab 2016;102:2821-6.

5 Gloyn AL, Pearson ER, Antcliff JF, et al. Activating mutations in the gene encoding the ATP-sensitive potassium-channel subunit Kir6.2 and permanent neonatal diabetes. $N$ Engl J Med 2004;350:1838-49.

6 Thurber BW, Carmody D, Tadie EC, et al. Age at the time of sulfonylurea initiation influences treatment outcomes in KCNJ11-related neonatal diabetes. Diabetologia 2015;58:1430-5

7 Gregg BE, Moore PC, Demozay D, et al. Formation of a human $\beta$-cell population within pancreatic islets is set early in life. J Clin Endocrinol Metab 2012;97:3197-206.

8 Malecki MT, Skupien J, Klupa T, et al. Transfer to sulphonylurea therapy in adult subjects with permanent neonatal diabetes due to KCNJ11-activating [corrected] mutations: evidence for improvement in insulin sensitivity. Diabetes Care 2007;30:147-9.

9 Babiker T, Vedovato N, Patel K, et al. Successful transfer to sulfonylureas in KCNJ11 neonatal diabetes is determined by the mutation and duration of diabetes. Diabetologia 2016;59:1162-6.

10 Chowdhury S. Puberty and type 1 diabetes. Indian J Endocrinol Metab 2015;19:51-4

11 Bowman P, Sulen Åsta, Barbetti F, et al. Effectiveness and safety of long-term treatment with sulfonylureas in patients with neonatal diabetes due to KCNJ11 mutations: an international cohort study. Lancet Diabetes Endocrinol 2018;6:637-46.

12 Bowman P, McDonald TJ, Knight BA, et al. Patterns of postmeal insulin secretion in individuals with sulfonylurea-treated KCNJ11 neonatal diabetes show predominance of non-K ATP -channel pathways. BMJ Open Diabetes Res Care 2019;7:e000721.

Copyright 2021 BMJ Publishing Group. All rights reserved. For permission to reuse any of this content visit https://www.bmj.com/company/products-services/rights-and-licensing/permissions/

BMJ Case Report Fellows may re-use this article for personal use and teaching without any further permission.

Become a Fellow of BMJ Case Reports today and you can:

- Submit as many cases as you like

- Enjoy fast sympathetic peer review and rapid publication of accepted articles

- Access all the published articles

Re-use any of the published material for personal use and teaching without further permission

Customer Service

If you have any further queries about your subscription, please contact our customer services team on +44 (0) 2071111105 or via email at support@bmj.com.

Visit casereports.bmj.com for more articles like this and to become a Fellow 